\title{
EFL Students' Perception of Speaking Course through Debating Process during the Pandemic
}

\author{
Sri Ayu Indah Lestari
}

sriayuindah24@gmail.com

Yousef Bani Ahmad

yousef.baniahmad@fkip.unsika.ac.id

\author{
Sumarta \\ sumarta@gmail.com
}

University of Singaperbangsa Karawang

\begin{abstract}
Speaking is one of four crucial skills in English language learning. The pupils communicate and share their thoughts by language in their everyday life. They use language to make an order, to communicate with others, to express their emotions, thoughts and ideas. Speaking is one of the subjects in an English Education Department, the researcher inspired to evaluate whether the debating method increase the student's speaking skill or not, especially during the outbreak of the corona virus. As the impact of this virus matter, education is one of some fields got impacted, so schools and universities are closed for more than a year. The new way of teaching learning could be a challenge for both students and instructors. Moreover, there is a need to know on how the students' perception toward the teaching learning process via video conference, was it feel the same. However, this paper investigates the EFL students' perception of speaking courses through the debating process during the pandemic. This study employing qualitative narrative inquiry. The data gathered from some the experiences of three Indonesian EFL students in university. The author was done collected the data conducted a semistructured interview using a call through messages application. The study found that the participants' perceptions toward speaking course conducted via video conference encourage their critical thinking, their team-work, students' social skill and their interest towards the subject. It seems that the debate technique is impacted the students positively by promoting their critical thinking, social skill, team work and students' satisfaction towards the subject.
\end{abstract}

Keywords: Perception; Speaking skill; Debate

\section{INTRODUCTION}

As the government announced in March 2020 that Indonesia was under lockdown, the teaching-learning process impacted, the courses are conducted through online learning. Yet, this online learning brings the dilemma of some teachers and of 
course the students. UNESCO (2020a cited in (Kirsch et al., 2021)) reported in April 2020 that around 1.5 billion (84.8\%) of children and adolescents in 172 countries cannot attend school during the pandemic that is happening all over the world. It has been more than a year since the government announced that schools are closed and teaching-learning processes are conducted through online courses to decrease the number of impacted people of the COVID-19.

Language is a tool for the human to communicate and deliver their thoughts, ideas, information, knowledge, and emotion. Language has been a useful tool in every human everyday life. Through language their exchange their thoughts such as in the debating process. Spoken language could be mastered by practice the language. During this certain condition, the courses of teaching-learning are conducted through the online-based platform. As stated by (Alhawsawi \& Jawhar, 2021), this sort of teaching and learning may include bundled self-directed course material and learning exercises in a variety of LMSs, as well as interactive online sessions using a variety of technologies.

There are two types of online courses; Asynchronous and Synchronous but, as the course conducted by the videoconferencing, synchronous type of method would be considered to be explained. Synchronous mode entails the delivery of course materials in real-time, synchronous software enables students and teachers to converse audibly, exchange messages via typing, upload PowerPoint presentations, stream videos, or surf websites jointly (Al-Nofaie, 2020).

Here are some reasons why this research is conducted during this time. First, this study tends to evaluate on teaching method of speaking in the teaching-learning process. By conducting this research, instructors could consider and implement this cooperative learning into their teaching-learning process. Second, the student's ability in discussing, exchange ideas, information, and opinion seems not in a good range for EFL students. Through this type of method, the researcher would like to know if this was an appropriate method to encourage their spoken skills and gain their insight into new perceptions in the learning process. As a branch of cooperative learning, this approach also brings up the emotional related, the students build their relationship with the others. Cooperative learning encourages students to collaborate in small groups to help one other enhance their own as well as others' learning (Jolliffe, 2012). The researcher could find the questions asked by interviewing EFL students at a university in Indonesia.

\section{LITERATURE REVIEW}

\section{Previous Study}

According to (Firmansyah \& Valatansa vegian, 2019) were done the study of the use of debate techniques in the teaching of the speaking process has been approved and the debating technique promotes pleasure in this type of teaching-learning. The study aims to seek out whether the debate could increasing the students' speaking 
skill and also to analyse the situation in the classroom during debating process. This study was done using Collaborative classroom research with 29 participants.

Based on (Desita, 2017) was conducted a study, the goal of the study is to increase students' speaking abilities in delivering opinions through discussion. The study used a classroom action research technique that consists of 3 cycles. The $8^{\text {th }}$ grade of 26 students were the focus of the study. The researcher utilized an observation checklist and a fiel to collect data. It reveals that debating strategy boosted students' speaking abilities in both giving and replying to other people's perceptions.

According to (Azka, 2017), this study focuses on students' perspective on the usage of argument in speaking class in particular. The study goal is to learn about and characterize students' perspective on the usage of debate in speaking class. This study used descriptive qualitative and the subject of the study is two $3^{\text {rd }}$ semester undergraduate English Department students. This tudy finding are the students have positive perceptions of the usage of debate, as a result of which it can be well accepted by students, and the students feel that debate is not only entertaining but also beneficial to the students' speaking skills and that this incorporates debate is valuable. The use of debate techniques in the training of the speaking process has been endorsed. Debate, on the other hand, is extremely concerned with how it may be used to improve one's speaking skills.

Teaching speaking through debate may be a fun experience for both the teacher and the student (Firmansyah \& Valatansa vegian, 2019). The researcher discovered that the debate approach was utilized by the students, even though the method is not directly applied in real life, and that the debate learning method increases the students' self-confidence (Azka, 2017).

\section{Perception}

Perception is made up of three parts. To begin, the perceiver is the one who attempts to comprehend and interpret a sensory event. The second is the perception's target. It is everything that the perceiver is attempting to comprehend and understand. The final point to mention is the situation. The context in which perception occurs was referred to as the situation; it could be an image on a street wall, a school, or an office, for instance (Roger, 2017) cited in (Awalya, n.d.).

In a line with this study, the perception of EFL students on the online learning method would be to evaluate the teacher to teach or deliver the course on the right way. Based on Roger (2017) cited in (Awalya, n.d.) perception can be characterized in two ways. a) First, it can be defined as the five-sensory experiences of items and people in the world, such as seeing, hearing, touching, smelling, and testing. b) Second, the term perception can refer to a mechanism that enables information to be derived from energy patterns that affect the sense organs. According to Noe (2004) cited in (Wibowo \& Khairunas, 2020), a blind individual tap-tapping his or 
her way through a congested room, experiencing it through touch, not all at once, but over time, through skillful probing and movement.

\section{Speaking skill}

Spoken language could be mastered by practice the language. Speaking ability, on the other hand, relates to the ability to communicate verbally in a practical, functional, and exact manner utilizing the target language (Zare \& Othman, 2015). During this certain condition, the courses of teaching-learning are conducted through the online-based platform. Speaking is used in the civilized world to express thoughts and connect with others (Firmansyah \& Valatansa vegian, 2019). Speaking is not only an operation creating, getting, and interpreting the information, and analyzing the speaking; it also has complex steps because it is about the situation and condition of speaking, such as the subject of speaking, the speakers' knowledge, the condition of the speakers' environment, and the purpose of speaking based on Florez, 1999 as cited in (Pratiwi \& Prihatin, 2021).

As stated in (Rybold, 2006), he recommends some tips to help to increase the learners' English skills. First and foremost, write your assignments before attending the class. Second, make sure to take notes in class. Third, maintain your organization. Fourth, examine the information. Fifth, ask questions. The last one is a practice to avoid poor performance. As Rost, 1994 in (Idrissova et al., 2015), the reasons for improving speaking skills. First, speaking allows the student to communicate with native speakers of the language. Because learners must interact to attain understanding access to native speakers of the language is vital. Second, the actual spoken language makes it difficult for the student to understand the language as the native language speaker use it. Speaking demands learners to comprehend not just how to produce certain elements of language, such as grammar, pronunciation, vocabulary (linguistic competence), but also they could understand when, why, and how to produce language (sociolinguistic competence).

\section{Debate}

When two or more people dispute positions that are incompatible with each other, a debate occurs (Johnson \& Johnson, 2014). Debate may help someone to become a better speaker in any conditions, private or public. It participates and has a voice in the argument. The debate also improves critical thinking and a variety of other abilities such as note-taking, organizing, researching, writing, listening, and teamwork-interpersonal relationship (Rybold, 2006). The adoption of the debate method as a teaching approach can help to promote the classroom more studentcentered, allowing students to take responsibility for their learning (Azka, 2017). The following are some of the elemts necessary fr spoken production (Harmer, 2001).

1. Connected speech

An effective English speaker should be able to produce fluent engliish words 'connected speech'. 
2. Expressive devices

A native speaker can change the pitch and stress of some statements, change the volume and tempo, and show others how they are feeling physically and non-verbally.

3. Lexis and grammar

Spontaneous speech is distinguished by the inclusion of a number of common vocabulary phrases, particularly in the execution of certain language functions.

4. Negotiation language

The use of negotiatory language is to request clarification and explain the structure of what we are saying is useful to effective speaking.

Debate, on the other hand, is particularly concerned with using it to develop students speaking ability as they are an enthusiast in rebate their opponent. The debate technique has the potential to develop students' speaking abilities, particularly in terms of the accuracy with which they communicate their opinions and fluency (Desita, 2017).

\section{METHOD}

\section{Design and Samples}

The method of this study used qualitative narrative inquiry. The subject of this current study is three EFL students that are in their $2^{\text {nd }}$ year in a university in Indonesia. The study used qualitative narrative inquiry. The participants were sophomore students in a university in Indonesia. During the data collection, the researchers collected the data and information through the online message platform by calling.

\section{Instrument and Procedure}

This study used narrative inquiry and the data collected by interviewing. Interviewing is motivated by a desire to learn about other people's lives on what were they went to and the importance they place on their experiences (Seidman, 2006). The online platform is the best choice to gather the data in this pandemic session. However, the researcher considered collecting the information of the participants used the application system such as WhatsApp as both researcher and participants agreed to do so. The participants should answer the question in Bahasa Indonesia as well as in English, it is to make them comfortable and free to spread their thoughts about the online course of speaking during the pandemic.

\section{Data Analysis}

To clarify, interviews will be manually analyzed, the thematic analysis would be used to examine the data already collected. Thematic analysis is a technique for 
identifying, analyzing, and reporting patterns (themes) in the data (Braun \& Clarke, 2006).

\section{RESULT AND DISCUSSION}

With respect to the aim of the research, the result of this study indicates that:

\section{Students' Satisfaction}

S1 : "Very satisfied because this method not only gains new understanding, but also mmm this method also makes us confident to talk to people, we know how to express opinions in front of people. Everyone has an opinion, but not everyone can express their opinion, like that."

Based on the data shown above, not only student's feedback seem satisfy of leaning speaking skill through video conference during this time but also the student increasing the new understanding, promote the student confidence, and encourage the student's to present their opinion.

S2 : "In my opinion, I feel quite satisfied with this method so I will give it a 7."

According to the data presented above, the students satisfied with the method and give the rate 7 out of 10 .

\section{S3 : "Of course, I am very satisfied with this debate method."}

From the data attached above, the student satisfy using video conference as a tool to delivering their arguments.

In short, the researcher found that the students enjoy class while the debating is in progress, even though the debating process is conducted using video conference. But the students seem that it is not make a big different than face to face learning process. Many students actively joined the class and paid attention to the process (Wahyuningsih, 2018).

\section{Self-confidence}

S1: "Yes, in my opinion, it adds new knowledge, more courage in terms of expressing opinions like that."

S1: "... this method also makes us confident to talk to people..."

As shown data above, the student encourage themselves to express their ideas towars the others, the instructor and students. 
S2 : Yes, there is. Since that activity, I have become more courageous to speak because the situation at that time forced me to speak, especially in English. This is in line with my expectations when participating in the activity.

Based on the dialog above, student also seem forced themselves to speak, by this the student gain their self-confidence indirectly.

S3: "I think this debate has made me more courageous in expressing my opinion because no one is watching, they only hear my voice through zoom."

As shown the data above, the debate also encourages the student to present their opinion, because no one watch.

The result of this study shows that through this type of method, the students agreed that this online learning promotes the students to deliver their arguments, expressing their ideas freely without anyone around them and it is also make the student to try themselves to speak up. It is also indicated that the students encourage themselves to deliver their arguments during the debating process. It is in line as stated in (Wibowo \& Khairunas, 2020) the adoption of online communication pushed pupils to speak up.

\section{With respect to other's perspective}

S1 : "oh yes yes, I think that in speaking I am also very good, because for sure we are, for example, if we are debating, our insight will increase, we can see other people's opinions, our opinions, I think the difference is good, I think. So what are the other aspirations, surely those aspirations are also good according to both parties like that."

The data shown that debate promotes the student's social skill, such as respecting other perspective.

S2 : "In my opinion, now I am more accepting of other people's opinions which I think are reasonable."

Based on the data above indicate that the student also increasing their social skills, even though the reason should be logic.

S3: "So from this method, I can understand and accept other people's opinions better."

The data shown above from last student also said it is gain his or her tolerance which could be mean as respect.

As shown by the data above, the researcher could conclude that through the debating process, socialization is build and respect of each other ideas. Also, the 
students respected the opponent side, encourage the students' critical thinking and curiosity. The students learned to tolerance and accept the others' perspective. As cited in (Rybold, 2006), the debate will teach you teamwork and people skills since, to succeed, you must collaborate and thinks as a team.

\section{Critical Thinking}

Critical thinking abilities and or higher-order thinking have garnered a lot of attention from educators, researchers, employers, and the media in recent years (Zare \& Othman, 2015).

S1: “... if students learn something they will build their understanding and certainly not all of their understanding is the same, using this method will definitely build new understanding, from here I can also build my critical thinking."

According to information presented that the understanding could be build by learning, and the understanding could build the student's critical thinking

S2 : "Of course it can make me think critically."

Based on the data, the student agree that debate improving his or her critical thinking.

S3: "From this, I have to prepare my argument so I have to think quickly and critically."

Based on the dialog above, students also agree that debate develops the students critical thinking.

This finding is consistent with that of (Rybold, 2006) the debate also fosters the development of various other skills that aid in good communication, such as critical thinking. They collect the information and comprehend what and how to battle the opponent side. Barkley (2005) cited in (Azka, 2017) stated that debate has three advantages for pupils. One of them is that "it encourages students' critical thinking and strengthens students' oral communication skills". It is effective to use debate in the video conference, as it is built their critical thinking.

\section{CONCLUSION}

The main goal of the current study was to determine EFL students' perception of EFL Students' Perception of Speaking Course through Debating Process during the Pandemic. This study has shown that the learners' perceptions of the debating process for speaking courses encourage students to deliver their arguments feely, join the class with the interest, this also promotes the students' critical thinking and their social skills. If someone is interested in an object such as a debate, they would 
pay attention and try to understand the process of it and involve in the debating process while in the debating process students need to give the feedback of the opponent side. The findings suggest that in general online teaching-learning for speaking skills could use the debate to develop the students' speaking skills or in any other subject as it encourages the students' critical thinking.

\section{REFERENCES}

Al-Nofaie, H. (2020). Saudi University Students' Perceptions towards Virtual Education During Covid-19 Pandemic: A Case Study of Language Learning via Blackboard. Arab World English Journal, 11(3), 4-20. https://doi.org/10.24093/awej/vol11no3.1

Alhawsawi, S., \& Jawhar, S. S. (2021). Negotiating pedagogical positions in higher education during COVID-19 pandemic: teacher's narratives. Heliyon, 7(6), e07158. https://doi.org/10.1016/j.heliyon.2021.e07158

Awalya, S. S. (n.d.). Students' Perception on the Use of English Debate Extracurricular to Improve Students 'Speaking and Critical Thinking Skill in SMA La Tansa. 2010, 234-248.

Azka, M. (2017). STUDENTS' PERCEPTIONS ON THE USE OF DEBATE IN SPEAKING CLASS: A CASE OF UNDERGRADUATE STUDENTS AT UNIVERSITAS MUHAMMADIYAH SURAKARTA IN 2016/2017 ACADEMIC YEAR. 21(2), 1689-1699. https://www.oecd.org/dac/accountable-effectiveinstitutions/Governance Notebook 2.6 Smoke.pdf

Braun, V., \& Clarke, V. (2006). Using thematic analysis in psychology Using thematic analysis in psychology. 0887(2006). https://doi.org/https://doi.org/10.1191/1478088706qp063oa

Desita, L. R. (2017). Improving Students' Speaking Ability through Debate Technique. 549, 40-42.

Firmansyah, D., \& Valatansa vegian, E. E. (2019). Improving the Students' Speaking Skill through Debate Technique. PROJECT (Professional Journal of English Education), 2(6), 891. https://doi.org/10.22460/project.v2i6.p891895

Harmer, J. (2001). The Practice of English Language Teaching.

Idrissova, M., Smagulova, B., \& Tussupbekova, M. (2015). Improving Listening and Speaking Skills in Mixed Level Groups (on the Material of New English File). Procedia - Social and Behavioral Sciences, 199, 276-284. https://doi.org/10.1016/j.sbspro.2015.07.517

Johnson, D. W., \& Johnson, R. T. (2014). Constructive controversy as a means of teaching citizens how to engage in political discourse. Policy Futures in Education, 12(3), 417-430. https://doi.org/10.2304/pfie.2014.12.3.417

Jolliffe, W. (2012). Cooperative Learning in the Classroom: Putting it into Practice Cooperative learning in the classroom: Putting it into practice. In Cooperative Learning in the Classroom: Putting it into Practice Cooperative learning in the classroom: Putting it into practice. https://doi.org/10.4135/9781446213971

Kirsch, C., Engel de Abreu, P. M. J., Neumann, S., \& Wealer, C. (2021). Practices 
and experiences of distant education during the COVID-19 pandemic: The perspectives of six- to sixteen-year-olds from three high-income countries. International Journal of Educational Research Open, 2-2(April), 100049. https://doi.org/10.1016/j.ijedro.2021.100049

Pratiwi, D. S., \& Prihatin, C. (2021). PROBLEMS AND DIFFICULTIES OF SPEAKING AT MUHAMMADIYAH LAMPUNG UNIVERSITY STUDENTS IN COVID PANDEMIC. 2(1), 40-49.

Rybold, G. (2006). Speaking, Listening and Understanding: debate for nonnativeEnglish speakers.

Seidman, I. (2006). Interviewing as Qualitative Research: a guide for researchers in education and the social science. In Teachers College, Columbia University New York and London. https://doi.org/10.1037/032390

Wahyuningsih, T. L. (2018). ENHANCING STUDENTS' SPEAKING SKILL THROUGH DEBATE TECHNIQUE. 1-12. https://doi.org/10.2991/icla17.2018 .18

Wibowo, A. I., \& Khairunas, S. (2020). Student's Perception of Online Learning for Public Speaking Course. LINGUA: Jurnal Bahasa, Sastra, Dan Pengajarannya, 17(2), 111-122. https://doi.org/10.30957/lingua.v17i2.640

Zare, P., \& Othman, M. (2015). Students' perceptions toward using classroom debate to develop critical thinking and oral communication ability. Asian Social Science, 11(9), 158-170. https://doi.org/10.5539/ass.v11n9p158 